\section{Utility of acute phase proteins as biomarkers of transport stress in ewes and beef cattle}

\author{
Francesco Fazio, ${ }^{1}$ Vincenzo Ferrantelli, 2 \\ Antonello Cicero, ${ }^{2}$ Stefania Casella, ${ }^{1}$ \\ Giuseppe Piccione ${ }^{1}$ \\ 'Dipartimento di Scienze Veterinarie, \\ Università di Messina; 'Istituto \\ Zooprofilattico Sperimentale della Sicilia \\ A. Mirri, Palermo, Italy
}

\begin{abstract}
The effect of transport on serum amyloid A (SAA), haptoglobin (Hp), Fibrinogen and white blood cells (WBC) was evaluated in 10 ewes and 10 beef cattle. All animals were transported by road for $6 \mathrm{~h}$ over a distance of about $490 \mathrm{~km}$ with an average speed of 80 $\mathrm{km} / \mathrm{h}$. Blood samples, collected via jugular venepuncture, were obtained before and after transport as well as after 12,24 and $48 \mathrm{~h}$ rest time. One-way repeated measures analysis of variance showed a statistically significant effect of sampling time on SAA, Hp, and WBC in ewes and beef cattle. Based on these results, Hp and SAA levels, together with WBC, may be useful indicators of animal health and welfare and in predicting the risk assessment in meat inspection.
\end{abstract}

\section{Introduction}

The transport is an inevitable husbandry practice that animals unexpectedly encounter in the livestock industry and can have implications for their welfare. In fact, transported animals are exposed to a variety of physical and psychological stimuli that disrupt their homeostasis and metabolism. Road transport, considered as one of the main causes of stress, may be more or less severe and affect a large number of systems. The effects of transport stress on animal health and welfare have been evaluated through behavioural, physiological and haematological variables (Adenkola and Ayo, 2010; Broom, 2003, 2008), mobilisation of energy and protein metabolism (Todd et al., 2000 ), activity of enzymes and hormones (Adenkola and Ayo, 2010; Stull and Rodiek, 2000 ), and the changes of immune system (Early and 0'Riordan, 2006). There is great scientific interest aimed at ensuring the welfare of transported animals and identifying easily obtainable biomarkers in relation to transport stress. In fact, stress experienced by farm animals during the transport may influ- ence the acute phase proteins (APPs) in beef cattle and ewes (Giannetto et al., 2011; Piccione et al., 2012) and also cause economic losses due to decreased carcass and meat quality (Teke et al., 2014). In the case of increased physiological stress or physical activity during the transport, muscle glycogen reserves may be used before slaughter. This can lead to higher ultimate meat $\mathrm{pH}$, darker meat colour, tougher meat and greater water holding capacity (Gregory, 1998). Acute phase proteins are a group of blood proteins linked to stress because their concentrations decrease (negative APPs) or increase (positive APPs) in response to external or internal challenges (Gonzàlez et al., 2008; Petersen et al., 2004; Ceron et al., 2005; Eckersall and Bell, 2010). In particular, serum amyloid A (SAA), haptoglobin (Hp) and fibrinogen (Fbg) in health monitoring programmes in livestock are useful for the identification of diseases or subclinical diseases. After considering that the linkage among animal health, welfare and APPs becomes more and more important, the aim of this study was to evaluate the modifications of serum concentrations of $\mathrm{Hp}, \mathrm{SAA}$ and Fbg, together with white blood cell (WBC), in order to identify the impact of transport on biomarkers. This will be increasingly useful to reduce transport stress that influences health, welfare and final quality of the meat of of ewes and beef cattle.

\section{Materials and Methods}

The study was carried out on 10 ewes and 10 beef cattle. Alla animals were clinically healthy. They were transported by road for $6 \mathrm{~h}$ over a distance of about $490 \mathrm{~km}$ with an average speed of $80 \mathrm{~km} / \mathrm{h}$, involving a combination of road surfaces ranging from small country lanes (10 km) through secondary roads $(60 \mathrm{~km})$ to motorways (420 km). All animals had no previous experience of road transport. The journey started at 08:00 a.m. and lasted $6 \mathrm{~h}$. Particularly, transport took place during spring, with an outside temperature of $18-20^{\circ} \mathrm{C}$ and $50-60 \%$ relative humidity. After road transport the animals were confined to paddock where environmental temperature was between 18 and $23^{\circ} \mathrm{C}$, and relative humidity was $50-65 \%$. After the transport the animals were fed hay $(2 \mathrm{~kg})$, wheat straw $(1 \mathrm{~kg})$ and wheat concentrate $(0.5 \mathrm{~kg})$. Water was available ad libitum. All animals were transported in accordance with Directive 1/2005 CEE (European Commission, 2005).

Blood samples were collected from each animal by jugular venipuncture into evacuated glass tubes (Venoject; Terumo Europe, Leuven, Belgium) before and after the transport as well as after 12,24 and $48 \mathrm{~h}$ rest time to determine
Correspondence: Stefania Casella, Dipartimento di Scienze Veterinarie, Università di Messina, viale Annunziata, 98168 Messina, Italy.

Tel. +39.090.3503520 - Fax: +39.090.3503975.

E-mail: stefania.casella@unime.it

Key words: Acute phase proteins, Road transport, Stress, Welfare, Meat quality.

Conflict of interests: the authors declare no potential conflict of interests.

Received for publication: 29 May 2014. Revision received: 19 September 2014 Accepted for publication: 19 September 2014

This work is licensed under a Creative Commons Attribution 3.0 License (by-nc 3.0).

(C) Copyright F. Fazio et al., 2015

Licensee PAGEPress, Italy

Italian Journal of Food Safety 2015; 4:4210

doi:10.4081/ijfs.2015.4210

the APPs. Each animal was sampled by experienced and skilled operators in less than $1 \mathrm{~min}$ to minimise handling stress affecting the results. The SAA concentration was performed with an enzyme-linked immunosorbent assay using ELISA kits (Tridelta Development, Maynooth, Ireland). The concentration of Hp was assessed using commercial colorimetric kits (Tridelta Development) in microplates, based on Hp-haemoglobin binding and preservation of the peroxidase activity of the bound haemoglobin at low $\mathrm{pH}$. The reading of absorbancies and the consecutive calculation of final concentrations of both APPs were performed on automatic microplate reader 0psys MR (Dynex Technologies, Denkendorf, Germany).

The concentration of Fbg was assessed on blood samples containing citrated sodium, after centrifugation, using a coagulometer (Clot 2S; SEAC, Florence, Italy). The WBC count was assessed on blood samples containing ethylenediaminetetraacetic acid using a multiparametric automatic analyser (HecoVet; SEAC).

One-way repeated measure analysis of variance (ANOVA), followed Bonferroni's multiple post-hoc comparison, was performed to determine the significant effect of sampling time in ewes and beef cattle. The level of significance was set at $<0.05$. Data were analysed using the software STATISTICA 8 (Stat Soft Inc.).

\section{Results}

The application of ANOVA showed a statistically significant effect of sampling time $(\mathrm{P}<0.05)$ on SAA, Hp and WBC in ewes and 
Table 1. Average values of serum amyloid A, haptoglobin, fibrinogen and white blood cells ( \pm standard deviation) and statistical significances measured during the experimental period in ewes.

\begin{tabular}{lccccc} 
Parameters & & \multicolumn{3}{c}{ Experimental conditions } & \\
& Before transport & After road transport & After $12 \mathrm{~h}$ & After $24 \mathrm{~h}$ & After $48 \mathrm{~h}$ \\
$\mathrm{SAA}(\mathrm{mg} / \mathrm{L})$ & $9.26 \pm 0.78$ & $9.33 \pm 0.56$ & $9.86 \pm 0.44$ & $10.11 \pm 0.55^{*}$ & $10.73 \pm 0.57^{\Delta}$ \\
$\mathrm{Hp}(\mathrm{g} / \mathrm{L})$ & $0.09 \pm 0.02$ & $0.11 \pm 0.03$ & $0.20 \pm 0.06$ & $0.29 \pm 0.08$ & $0.44 \pm 0.07^{\Delta}$ \\
\hline Fbg $(\mathrm{g} / \mathrm{L})$ & $2.04 \pm 0.24$ & $2.12 \pm 0.31$ & $1.97 \pm 0.34$ & $1.98 \pm 0.47$ & $2.11 \pm 0.30$ \\
WBC $(\mathrm{K} / \mu \mathrm{L})$ & $10.78 \pm 0.82$ & $11.36 \pm 0.88$ & $11.22 \pm 0.78$ & $11.45 \pm 1.06$ & $12.54 \pm 0.98$ \\
\hline
\end{tabular}

SAA, serum amyloid A; Hp, haptoglobin; Fbg, fibrinogen; WBC, white blood cells. *After $24 \mathrm{~h} v$ s before transport; ${ }^{\wedge} \mathrm{after} 48 \mathrm{~h} v$ s before transport.

Table 2. Average values of serum amyloid A, haptoglobin, fibrinogen and white blood cells ( \pm standard deviation) and statistical significances measured during the experimental period in beef cattle.

\begin{tabular}{|c|c|c|c|c|c|}
\hline \multirow[t]{2}{*}{ Parameters } & \multicolumn{5}{|c|}{ Experimental conditions } \\
\hline & Before transport & After road transport & After $12 \mathrm{~h}$ & After $24 \mathrm{~h}$ & After $48 \mathrm{~h}$ \\
\hline $\mathrm{SAA}(\mathrm{mg} / \mathrm{L})$ & $15.40 \pm 1.56$ & $20.00 \pm 4.55$ & $23.50 \pm 3.98$ & $55.50 \pm 3.54 *$ & $101.90 \pm 15.26^{\sharp}$ \\
\hline $\mathrm{Hp}(\mathrm{g} / \mathrm{L})$ & $0.18 \pm 0.03$ & $0.21 \pm 0.03$ & $0.22 \pm 0.20$ & $0.23 \pm 0.03^{\circ}$ & $0.38 \pm 0.03^{\#}$ \\
\hline $\mathrm{Fbg}(\mathrm{g} / \mathrm{L})$ & $4.00 \pm 0.81$ & $4.54 \pm 0.49$ & $4.34 \pm 0.59$ & $4.16 \pm 0.35$ & $4.26 \pm 0.60$ \\
\hline $\mathrm{WBC}(\mathrm{K} / \mu \mathrm{L})$ & $8.49 \pm 1.01$ & $9.08 \pm 0.89$ & $9.36 \pm 0.88$ & $9.52 \pm 0.61$ & $10.21 \pm 0.81^{\bullet}$ \\
\hline
\end{tabular}

SAA, serum amyloid A; Hp, haptoglobin; Fbg, fibrinogen; WBC, white blood cells. *After $24 \mathrm{~h}$ vs before transport; ${ }^{\circ}$ after $48 \mathrm{~h} v$ sefore transport and after road transport; ${ }^{\circ}$ after $24 \mathrm{~h} v s$ before transport, after road transport and after $12 \mathrm{~h}$; ${ }^{\sharp}$ after $48 \mathrm{~h}$ vs before transport, after road transport, after $12 \mathrm{~h}$ and after $24 \mathrm{~h}$.

beef cattle. Tables 1 and 2 show average values of all studied parameters, expressed in conventional units of measurement with standard deviations and statistical significances, measured during the experimental period in ewes and beef cattle.

\section{Discussion}

All data obtained before transport were within the physiological range referred to in the literature for ewes and beef cattle (Eckersall and Bell, 2010; Ganheim et al., 2003; Jain et al., 2011). The results of this study confirmed that a linkage between stress and APP response exists. Particularly, SAA and Hp increased both in sheep and beef cattle during the rest time relative to changes from pre-transportation values. In sheep SAA increased significantly after 24 and $48 \mathrm{~h}$ of road transport, while Hp increased significantly after $48 \mathrm{~h}$ of road transport only. In beef cattle the results showed a statistically significant increase of $\mathrm{Hp} 24 \mathrm{~h}$ after transport and of SAA compared to the previous data points, and $48 \mathrm{~h}$ after transport. Both parameters reached statistically significant higher values. As previously demonstrated, the SAA concentration tends to increase rapidly, whereas Hp concentration increases at a slower rate during the acute phase response (Colditz et al., 2005; Eckersall et al., 2007), which is consistent with the findings of the present study. It has also been reported that the stimuli can induce different APPs response which may account for the different SAA concentration compared to the hp concentration observed (Lepherd et al., 2011). Lomborg et al. (2008) demonstrated marked
SAA responses in healthy adult cattle after exposure to complex stressors as road transport. In fact, these results are in agreement with studies of other researchers who emphasised the role of APPs not only with inflammation but also with some conditions such as road transport which can be highly stressful and compromise welfare (Petersen et al., 2004). When ewes and beef cattle are stressed, there is a rapid relase of cathecolamines which results in glycogen depletion causing a lower rate of post-mortem lactic acid synthesis and hight ultimate $\mathrm{pH}$, undesirable colour, making such dry beef (Marenčić et al., 2012). The APPs assay may have a potential role for monitoring adverse environmental and/or management stressors, thus enabling better animal welfare practice (Piñeiro et al., 2007; Murata, 2007). Consequently, the APPs represent important biomarkers of stress during the road transport of ewes and beef cattle. This is interesting not only to monitor the health status and welfare of transported animals but also to improve meat quality characteristics of ewes and beef cattle.

\section{Conclusions}

Modern veterinay medicine is increasingly focusing on prevention rather than cure and these biomarkers are important factors for the animal's environment and welfare. In particular, the results of this study suggest that SAA and Hp levels, together with WBC, may be useful indicators of animal health and welfare and good predictors of risk assessment in meat inspection.

\section{References}

Adenkola AY, Ayo J0, 2010. Physiological and behavioural response of livestock to road transportation stress: a review. Afr J Biotechnol 9:4845-6.

Broom DM, 2003. Transport stress in cattle and sheep with details of physiological, ethological and other indicators. Dtsch Tierarztl Wochenschr 110:83-9.

Broom DM, 2008. The welfare of livestock during road transport. In: Appleby M, Cussen V, Garces L, Lambert L, Turner J, eds. Long distance transport and the welfare of farm animals. CABI, Wallingford, UK, pp 157-81.

Ceron JJ, Eackersall PD, Martinez-Subiela S, 2005. Aute phase proteins in dogs and cats; current knowledge and future perspectives. Vet Clin Path 34:85-99.

Colditz IG, Walkden-Brown SW, Daly BL, Crook BJ, 2005. Some physiological responses associated with reduced wool growth during blowfly strike in Merino sheep. Aust Vet J 83:695-9.

Early B, 0'Riordan EG, 2006. Effects on transporting bulls at different space allowance on physiological, haematological and immunological responses to 12 -h journey by road. Irish J Agr Food Res 45:39-50.

Eckersall PD, Bell R, 2010. Acute phase proteins: biomarkers of infection and inflammation in veterinary. Vet $\mathrm{J}$ 185:23-7.

Eckersall PD, Lawson FP, Bence L, Waterston MM, Lang TL, Donache W, Fontaine MC, 2007. Acute phase protein response in an experimental model of ovine caseous lymphadenitis. BMC Vet Res 3:1-6.

European Commission, 2005. Council 
Regulation of 22 December 2004 on the protection of animals during transport and related operations and amending Directives 64/432/EEC and 93/119/EC and Regulation (EC) No 1255/97, 1/2005/EC. In: Official Journal, L 3, 05/01/2005, p 1-44.

Ganheim C, Hulten C, Carlsson U, Kindahl H, Niskanen R, Waller KP, 2003. The acute phase response in calves experimentally infected with bovine viral diarrhoea virus and/or Mannheimia haemolytica. J Vet Med B 50:183-90.

Giannetto C, Fazio F, Casella S, Marafioti S, Giudice E, Piccione G, 2011. Acute phase protein response during road transportation and lairage at a slaughterhouse in feedlot beef cattle. J Vet Med Sci 73:15314.

Gonzàlez FHD, Tecles F, Martìnez-Subiela S, Tvarijonaviciute A, Soler L, Ceròn JJ, 2008. Acute phase protein response in goats. $\mathrm{J}$ Vet Diagn Invest 20:580-4.

Gregory NG, 1998. Animal welfare and meat science. CABI Publ., Wallingford, UK, p 304.
Jain S, Gautam V, Naseem S, 2011. Acutephase proteins: as diagnostic tool. J Pharm Bioallied Sci 3:118-27.

Lepherd ML, Canfield PJ, Hunt GB, Thomson PC, Bosward KL, 2011. Assessment of the short-term systemic effect of and acute phase response to mulesing and other options for controlling breech flystrike in Merino lambs. Aust Vet J 89:19-26.

Lomborg SR, Nielsen LR, Heegaard PM, Jacobsen S, 2008. Acute phase proteins in cattle after exposure to complex stress. Vet Res Commun 32:575-82.

Marenčić D, Ivankovi A, Pinti, Kelava N, Jakopovi T, 2012. Effect of the transport duration time and season on some physicochemical properties of beef meat. Arch Tierzucht 55:123-31.

Murata H, 2007. Stress and acute phase protein response: an inconspicuous but essential linkage. Vet J 173:473-4.

Piccione G, Casella S, Giannetto C, Giudice E, Fazio F, 2012. Utility of acute phase proteins as biomarkers of transport stress in ewes. Small Ruminant Res 107:167-71.
Petersen HH, Nielsen JP, Heegaard PMH, 2004. Application of acute phase protein measurement in veterinary clinical chemistry. Vet Res 35:163-87.

Piñeiro M, Pineiro C, Carpintero R, Morales J, Campbell FM, Eckersall PD, Toussaint MJ, Lampreave F, 2007. Characterization of the pig acute phase protein response to road transport. Vet J 173:669-74.

Stull CL, Rodiek AV, 2000. Physiological responses of horses to 24 hours of transportation using a commercial van during summer conditions. J Anim Sci 78:145866.

Teke B, Akdag F, Ekiz B, Ugurlu M, 2014. Effects of different lairage times after long distance transportation on carcass and meat quality characteristics of Hungarian Simmental bulls. Meat Sci 96:224-9.

Todd SE, Mellor DJ, Stafford KJ, Gregory NG, Bruce RA, Ward RN, 2000. Effects of food withdrawal and transport on 5 to 10 day old calves. Res Vet Sci 68:125-34. 